\title{
THE PERCEPTIONS AND PRACTICES OF SECONDARY SCHOOL TEACHERS FOR DEVELOPING CRITICAL THINKING SKILLS IN STUDENTS
}

\author{
Samina Ali \\ M. Phil Scholar, Department of Educational Development, \\ Karakorum International University \\ samina87@gmail.com \\ Sadruddin Bahadur Qutoshi \\ Assistant Professor, Department of Educational Development, \\ Karakorum International University \\ sadruddin.qutoshi@kiu.edu.pk \\ Zahra Jabeen \\ Lecturer, Department of Educational Development, \\ Karakorum International University \\ zahra.jabeen@kiu.edu.pk
}

\begin{abstract}
Critical thinking is a multifaceted process which requires a higher level of cognitive skills. Teachers' perceptions and practices to develop critical thinking skills among students influence their behavior in the class. This study intended to explore the perceptions and practices of secondary school teachers in developing the critical thinking skills of students. Four secondary teachers were conveniently selected for data collection by using a semi-structured interview followed by classroom observation and document analysis. The collected data was analyzed by using a thematic approach. The findings of the research study indicated that some of the secondary school teachers lack the basic knowledge about critical thinking; therefore, they were unable to define the concept of critical thinking and way to develop these skills in their students. Most of the teachers (i.e., 66.6\%) were aware that it is important to develop student's critical thinking skills but except one, other teachers were unable to provide evidence of using effective classroom strategies needed to develop critical thinking skills among students. Moreover, it was observed that students were unable to analyze and apply their knowledge in new situations. Based on the findings, it was recommended that schools need to train teachers on pedagogies to enable them to create interactive classrooms to lead students to think critically.
\end{abstract}

Keywords: critical thinking, reasoning skills, rote learning, teaching approaches

\section{INTRODUCTION}

Critical thinking is a form of reflective thinking over information and arguments, which involves the analysis and evaluation of existing communication by being logical (Browne \& Keeley, 2011). It refers to analyzing and evaluating information, reasoning and situations, according to appropriate standards such as truth and logic, for the purpose of constructing sound and insightful new knowledge, understandings, hypotheses and beliefs. It is the ability of an individual to process and synthesize information in such a way that it enables them to apply it judiciously to tasks of decisionmaking and effective problem-solving (Heard et al., 2020).

Critical thinking is one of the 21st century skills to survive in the era of globalization, telecommunication, and digital technology (Lai, 2011; Khoiri, Komariah, Utami, Paramarta \& Sunarsi, 2021). With the evolution of the technology and its critical role to improve teaching and learning practices at any stage of educational endeavors (Qutoshi, 2017; Qutoshi et al., 2020), it is possible for learners to access information from anywhere at a single press of a button. However, it is now challenging for educators to develop the ability and skills of learners not only to assess new information but also to analyze, evaluate, and interpret the information on a diverse range of disciplines to create new meanings out of the available information (Macagno \& Bigi, 2020; Liyanage; Liyanage, Walker \& Shokouhi, 2021), teachers' education is not an exception. Advanced 
societies require people who can think well and make good decisions, and helping learners to develop thinking skills is important because it is a demand of job market in a complex and rapidly changing global economy (Cotton, 1991 as cited in Smith \& Szymanski, 2013; Duron, Limbach \& Waugh, 2006; Short \& Keller-Bell, 2021). To develop students' thinking ability, it is important that teachers first develop conceptual understanding about critical thinking and its importance. Teachers need to dedicate time and effort to incorporate these skills through effective teaching, so that they can nurture their students as critical thinkers (Ridho, Wardani \& Saptono, 2021). Ball and Gartan (2005) suggested that when educators prepare learners for higher levels of cognitive thinking, it is important to be a role model for them by adopting high-level thinking in their approach to teaching. Research studies revealed that teachers' ability to think critically, teaching strategies and classroom environment influences students thinking skills (Simpson \& Courtney, 2002; Kong, 2006; Mangena \& Chabeli, 2005).

Research revealed that most teachers have little understanding and knowledge about critical thinking skills; therefore, it is difficult for teachers to engage students in activities to develop higher order thinking skills (Choy \& San Oo, 2012; Paul, 2010; Ridho, Wardani \& Saptono, 2021). Teachers often perceive that critical thinking skills need to be taught; however, research indicates that they do not understand critical thinking skills sufficiently enough to incorporate those skills into their lessons (Paul, 2005; Cotton, 1991 as cited in Smith \& Szymanski, 2011). It is evident that the majority of the secondary teachers use the lecture method (with one directional flow of information as dictating), which is teacher centered and traditional approach; hence, it is not possible to develop students thinking ability by using this approach in classrooms (Choy \& Cheah, 2009; Ridho, Wardani \& Saptono, 2021). Moreover, teachers are unable to use interactive teaching strategies and provide constructive and meaningful learning environments in the classroom. Furthermore, content dominant curriculum binds teachers to cover the syllabus before the finals, which limits students learning and cognitive development (Aliakbari \& Sadeghdaghighi, 2012). In Pakistan, teachers usually emphasize on teaching content and encourage students to recall and memorize the given information rather than making learning meaningful and challenging students to reason, question, and search for other options (Government of Pakistan \& World Bank, 2006). This lead to rote memorization which is one of the major hindrances in developing critical thinking skills among students in Pakistan (Jamil \& Muhammad, 2021).

In the context of Gilgit-Baltistan, researchers observed the practices of teachers at different levels appeared to be non-conducive for nurturing critical thinking skills in students. For instance, respondents contended that their teachers never encouraged them to think critically. However, teachers mostly encourage students to remember concepts through rote memorization. As a result of such practices, students cannot think out of the box and are unable to solve problems posed to them during their studies at school and in real life situations. In Pakistan, school students are unable to develop interactive skills like reasoning, questioning, and thinking because their classroom environment and teaching methodologies do not emphasize on these cognitive skills to exercise their thinking abilities (Government of Pakistan, 2006). Moreover, teachers force students to recall and memorize the right answer instead of motivating and engaging them to apply, analyze, evaluate and search for other options to come up with innovative ideas (Mahmood, 2006). Thus, this study intended to examine the perception of secondary school teachers about critical thinking, and the role of their teaching practices in developing critical thinking skills among students. It is important to investigate if teachers have the knowledge of critical thinking models and skills in a classroom.

\section{LITERATURE REVIEW}

Critical thinking skill has been defined in different ways by many researchers. For instance, according to Encarta (2009), critical thinking is the ability to think reasonably and analytically. An individual observes, experiences, and gives reflective judgments in the form of written or verbal arguments. Consequently, critical thinking involves determining the meaning and significance of what is observed or expressed, or concerning a given inference or argument, determining whether there is adequate justification to accept the conclusion as true. In other words, critical thinking is a means of thinking about any subject, content or problem, in which individuals improve the quality of their thinking. 
Twenty-first century demands new skills and information, which includes critical thinking, exploring, evaluating, reasoning information, problem solving, and developing analytical and effective communication skills (Lai, 2011). The primary objective of education is to develop advanced skills and abilities in learners, such as observational, reasoning, analyzing, evaluating and problem solving, so they can face and resolve real life challenges (Hashim, Ismail \& Kuldas, 2013). Similarly, Zarillo (2012) stated that the institutions should focus on evaluating how students are learning and applying given information rather than using standardizing testing abilities. According to the National Education Policy (2009), one of the key objectives of education is to help and develop critical thinking skills at all levels in the schools. Hoodbhoy (2009) argued that in Pakistan, students are trained and prepared to just complete their degree, and students cannot comprehend, analyze, present, and apply their own ideas and knowledge in the real world. He further added that students lack the basic life skills which could help them to face real life challenges. Aliakbari and Sadeghdaghighi (2012) argued that critical thinking skills are not inherent or inborn abilities. These skills need to be developed through long term practice and experiences. It is important to encourage and develop these skills and enable students to connect with the outer world. Similarly, Snyder and Snyder (2008) suggested that through effective teaching strategies and long-term dedicated practices of teachers it is possible to develop critical thinking abilities of students. Thus, critical thinking skills require multiple cognitive abilities and personal characteristics as well as the right motivation and an enriching environment (Fletcher, 2011; Lewis \& Smith, 1993). It means that teachers need to be very consciously aware about their own skills, abilities, knowledge and attitude towards critical thinking skills so as to enable their students to be critical thinkers.

Lauer (2005) claimed that teachers have a little knowledge about critical thinking skills; therefore, it is difficult for them to engage students in different activities to develop their critical thinking skills. Similarly, Choy and Oo (2012) stated that most of the teachers are not aware of the importance of their critical thinking skills, so they are unable to use effective strategies needed to develop these skills (Elder \& Paul, 2010). Thus, teachers need to expose their students to a diverse range of teaching methods, which promote critical thinking skills in order to nurture their thinking process. Moreover, teachers can use various strategies to influence and improve students' thinking abilities, such as problem solving, justifying and judging the arguments, interpreting and concluding the topics under discussion. Furthermore, teachers should inculcate critical thinking and inquirybased problems in their teaching practices, which would directly enhance the academic achievement of the students (Connor, Morrison \& Petrella, 2004). Teachers can use a variety of activities, such as using diagrams, mind mapping and graphics images to help students visualize given information in a more meaningful way. Similarly, Gürses, Açıkyıldız, Doğar, and Sözbilir (2007) suggested that creative discussions and project-based activities encourage critical thinking and problem-solving skills. Most of the people would learn much better through activities and observation rather than learning through rote memorization. These creative methods would include experimenting, questioning, testing, observing, and exploring (Scriven \& Paul, 2008; Templeaar, 2006).

According to King, Goodson and Rohani (2009), the environment of the classroom should be appealing and encouraging for the students. Non supporting environment of the classroom influences the students' reasoning and problem-solving skills. Appropriate teaching strategies and learning environments facilitate the growth of higher order thinking ability and enhance student's persistence, self-monitoring, open-minded and flexible attitudes (Smith, Sasone \& White, 2007). Students' progress and improvement in the classroom is based on the teacher's style and attitude; the classroom environment and the instructional strategies the teacher employed can motivate students to learn and think on higher levels (Orr \& Klein, 1991). Teacher's positive attitude and interactive classroom environment enhance the students' learning (Osterman, 2000; Fredericks, Blumenfeld \& Paris, 2004).

Besides teachers' lack of knowledge about critical thinking skills, there are many obstacles in developing students' critical thinking skills. According to the Economic survey of Pakistan (2011), challenges faced by Pakistani schools are shortage of teachers, large number of students in classrooms, unavailability of trained teachers and resources, and lack of adequate research etc. School curricula are often content dominated (i.e., curriculum as subject matter and textbooks etc.), making teaching mainly a knowledge transfer process rather than focusing on middle order and higher order thinking skills by focusing on curriculum as experience and curriculum as mosaic (Qutoshi, 
2021). Similarly, Sultana and Zaki (2015) reported that Pakistani teachers are bound and forced to cover the school syllabus. In this pressure, teachers are unable to assist and pay individual attention to each student, which is a great psychological and social need of students. Teachers are unable to provide a constructive and meaningful learning environment in a classroom because they are bound to cover the syllabus before the end terms. Moreover, assessment systems bind teachers to focus on teaching content and force their students to memorize and recall information instead of involving students in meaningful activities. To measure students' thinking and reasoning ability, it is important to develop their problem-solving skills and encourage and involve students in classroom discussions. Unfortunately, the classroom environment and teaching methods adopted by teachers in Pakistan do not consider the individual differences of the learners (Sultana \& Zaki, 2015).

From given literature, it is indicated that the teachers are using traditional methods of teaching, such as lecture method with one-directional flow of information without the involvement of learners lead them to emphasize on recall and memorization of information without any practical demonstration (Jalal et al., 2020; Orland-Barak \& Wang, 2021). This means that these teachercentered approaches could hardly develop students' thinking skills with a specific focus on remembering and understanding the level of the knowledge acquisition (Qutoshi \& Poudel, 2014; Choy \& Cheah, 2009). Thus, teachers need to develop an interactive, encouraging and learnercentered teaching approach in classrooms to help students to think (Short, \& Keller-Bell, 2021) about applying and analyzing the knowledge that they gained in their classroom to experience higher-order thinking skills by evaluating and creating new knowledge (Qutoshi, 2018; Schroeder, 2003).

\section{RESEARCH DESIGN}

A qualitative research paradigm was employed to study and explore the teacher's perception and practices to develop critical thinking skills in their students. Qualitative research design is used extensively when researchers want to study human behavior and habits to explore and understand a particular issue or topic (Creswell, 2014). According to Bogdan and Biklen (1998), the basic aim of qualitative research is to discover individual views, thoughts, and experiences to understand human behavior and experiences. Therefore, the aim of using qualitative design is to gain a deep and holistic understanding of secondary school teachers' perception and practices in developing critical thinking skills in real classroom settings.

Under the qualitative paradigm, the researchers used a qualitative case study design to collect data. The case study is a method for exploration of facts through using different tools for detailed data collection (Merriam, 1998). Maxwell (2005) stated that qualitative case study design helps to explore and analyze in-depth knowledge of a single phenomenon such as the perceptions and practices of secondary school teachers in this study. Therefore, the case study design was a suitable approach for exploring and understanding the perception and practices of teachers in the classroom to generate detailed contextual data. Case study research encourages the use of various data collection tools for in depth analysis of particular issues or a topic (Yin, 2009). Therefore, in this study, the researchers used semi-structured interviews, observation (non-participant) and document reviews. Data was collected from multiple techniques which help the researchers in triangulating data such as interviews (semistructured), classroom observation (formal observation with a checklist) and document analysis (lesson plans, students' notebooks, books etc.). These research tools helped the researchers to get a detailed and critical insight into the perceptions and practices of teachers for developing critical thinking skills among students in school.

Convenient sampling was used as a sampling strategy for the study. Convenient sampling helped researchers to easily select the willing participants who are representative of the population in a minimum possible time (Etikan, Musa, \& Alkassim, 2015). Rationale for using a convenient sampling strategy was that including every subject in the study was difficult and time consuming, so researchers selected the teachers who were easily accessible and willing to participate in the research. The four interview participants were secondary level teachers and subject specialists with a minimum five years of teaching experiences.

\section{RESULTS}

\section{Secondary School Teachers' Perception about Critical Thinking}


The findings of the study revealed that most of the secondary school teachers lack basic knowledge about critical thinking, and could not even define the concept explicitly. However, the majority of the teachers agreed that it is important to develop students' critical thinking skills (Ridho, Wardani \& Saptono, 2021). 33.3\% of the teachers expressed their views about some basic steps towards developing critical thinking skills in students. In addition to this, it was found during classroom observations, that for secondary school teachers, critical thinking means asking questions and giving responses to the teachers in order to grasp the main idea of the topic under discussion in the class. One of the teachers said, "critical thinking means the ability to grasp the main idea of the topic/lecture". Similarly, another teacher shared her views in these words, "if the student is able to understand $10 \%$ of the given information and ask questions related to the topic, that means he/she is involved in the process of thinking". Moreover, another teacher expressed that "critical thinking is an ability to solve problems according to one's mental level".

During the document review phase, it was discovered that the Oxford syllabus for secondary school students explicitly includes information, objectives, activities, material, and teaching strategies for developing higher-level thinking skills. However, during classroom observations, it was shown that the teachers were not following those instructions and objectives mentioned for each chapter. The term "critical thinking" is mentioned in curriculum objectives, educational aims, and goals in educational policies. Contrary to this, most of the teachers were unable to define and explain the concept of critical thinking.

\section{Teacher's Perceptions Regarding Student's Ability to Think Critically}

In response to the question about teachers' perception about student's ability to think critically, teachers responded in these words, "I think students' past experiences of school times are not encouraging and motivating them to question and reason in the classroom. Therefore, every student in the classroom was not actively participating during the lesson." Another teacher said, "In my classroom, maximum students have reasoning and thinking ability, but few students, who are slow learners, resist mental efforts".

\section{Teaching Strategies to incorporate higher order thinking skills in students}

Responding to these questions from the participants, "What strategies did they use in their classrooms? and What opportunities do the teachers provide students to foster their thinking skills? One of the teachers responded, "For developing critical thinking skills in students, I develop hands-on and minds-on activities. The students enjoy outdoor activities more than indoor activities. I always try to make my lessons more interesting by using maps, globes, pictures, and outdoor observations".

During classroom observation, the researchers noticed that some teachers involved their students in different indoor and outdoor activities and gave opportunities to students to experience, explore, observe, think and share their learning with the class. Students were not bound to textbook content, and they were discussing and sharing their knowledge with the class.

Most of the teachers said that one of the important strategies they used in the classroom to motivate students is to think and share their ideas with the class. One of the teachers shared, "I always encourage my students to do self-study and arrange group discussions, so students are able to share their ideas with other peers in the class. I appreciate my students when they ask logical questions during the lecture. I usually engage students in a brainstorming activity before starting the lesson so that they can share their previous knowledge and experiences related to the topic. One teacher stated that "I try to encourage my students to think, identify and share examples related to the topic". It was observed that the teachers used to write the topic on the board, read from the textbook, and orally explained the content to the students.

While reviewing the lesson plan, it was noticed that the objectives were not clear in the lesson and the six levels of Bloom's revised taxonomy were not considered. Most of the teachers were unable to provide their lesson plans. The researchers kept requesting the teachers to share their lesson plans, but teachers informed at the end that they do not write lesson plans.

\section{Classroom environment to motivate and engage students in thinking process}

When the researchers further probed and asked participants about how their classroom environment helped students to engage in higher-order thinking. The participant responded, "as a teacher, I am not 
in favor of chalk and talk methodology. I try to demonstrate the lesson through pictures, charts and maps. I always discourage rote learning and restrict my students not to copy the answers from the book". The researchers noticed that one teacher was encouraging and involving the students in different mental activities. She was using the lecture method through engaging the students in the classroom. For example, she used different AV aids during the lesson and demonstrated the topic to attract the students in the classroom. The teacher tried to use some appropriate strategies to create a learning environment in the classroom

Another teacher responded that 'I appreciate students' effort and motivate them to share their knowledge and experiences. I also provide extra time to students to do research, and to involve themselves in the thinking process. I think my classroom environment is very encouraging". However, during the classroom observation, the researchers observed that the classroom environment was very traditional and students were passive most of the time. The teacher was not encouraging the students to participate, nor use any teaching aid or material except textbooks and whiteboard. Most of the students in the classroom were talking to each other and were not listening carefully to the lecture.

Moreover, another teacher shared the view that "I always encourage students' participation in the classroom. I also give a positive response when they need guidance. I motivate my students to share their ideas and knowledge, and also encourage them to do extra study and to do research about different topics". The researchers noticed that most students were not active and unable to concentrate during lectures. The teacher was unable to motivate and create an active learning environment in the classroom. During observation, the researchers noticed that the teachers used an authoritative style of teaching, and the classroom environment was not interactive. Most of the students were hesitant to discuss or to ask any questions from teachers because of their authoritative attitude in the classroom. It is demonstrated that the majority of the teachers do not use interactive methods in the classroom to involve students in the learning process. The classroom environment was not appealing and encouraging for the students. Teaching strategies, normally used by the teacher, were teachercentered, as a result, they could not create a motivating and exciting learning environment in the classroom.

\section{Strategies to Assess Critical Thinking Skill}

In response to the question from the participants, "what strategies were used in the classroom to assess the thinking skills of the students?" One of the teachers responded: "I ask questions during the lecture while evaluating their responses. I check their work individually". Study revealed that the teacher used the map to identify/find the location of a particular country on the map. Then they were asked to guess the climate, living style, culture, and hobbies of the people living in the different locations on the map. Most of the students were active and they were very good at using maps and globes. Researchers observed that the teacher engaged students by asking frequent questions. Moreover, the students were engaged in meaningful activities during class. Another teacher responded that she keeps assessing the critical thinking skills of the students whenever they respond to the given oral or spoken tasks. In the classroom, during observation, she was asking questions to evaluate students' learning; however, students were not provided equal opportunities because it was observed that few of the students were ignored in the class. One teacher responded, "Asking questions by the students in the class means they are engaged. I keep evaluating my students by checking whether their responses are memorized responses or answers with logical reasoning".

It was noticed that some research participants did not feel comfortable in being observed by the researchers. The study also indicated that some teachers did not consider the importance of critical thinking in their teaching activities. Therefore, their students showed poor performance in doing simple tasks based on logic and reason.

\section{DISCUSSION AND CONCLUSION}

The study revealed that the majority of the secondary school teachers had little awareness and understanding about the concept of critical thinking; however, they could realize the importance of developing critical thinking skills in students as an important classroom activity. Studies such as Paul and Stapleton (2010), and Qutoshi (2018) argued that teachers need to develop clear concepts about critical thinking and should use effective strategies in their classrooms to develop critical thinking skills. However, the participants of this study appeared to be less aware of such kinds of strategies and 
could not motivate their students to develop their critical thinking skills. From the findings of the study, it could be inferred that teachers need to walk the talk about their awareness of the concepts and their teaching practices in a classroom. This shows that teachers need to develop clear concepts about critical thinking skills and need to follow the syllabus guidelines that are provided to improve their students' learning skills.

Moreover, the findings indicated that most of the teachers did not even know how to define critical thinking and they had little knowledge about critical thinking skills. As a result, it is difficult for teachers to engage students in different activities to develop critical thinking skills in their classrooms (Lauer, 2005), because majority of the teachers lack these skills, resultantly, it becomes extremely difficult to develop critical thinking skills in their students. Therefore, schools need to focus on developing high-order thinking skills in their teachers to make them capable of developing their students' higher order thinking.

Data revealed that despite the fact that syllabus was enriched with a lot of information with clearly defined objectives for each lesson, and the activities were based on higher-level ordered thinking; however, the teachers were found to be in a state of "comfort zone" and they do not focus on those objectives, and seem to critique the school for not providing the required instructional material to improve the teaching and learning of students. This means that their possible target is not higherorder thinking skills, but middle order thinking by applying the knowledge with application-based learning.

Findings unveiled the fact that teachers were unable to develop and create an effective classroom environment for developing critical thinking in their students. For example, teachers could not be able to create a conducive, yet challenging learning environment for students to think critically and focus on out-of-the-box thinking to share their innovative ideas related to the knowledge they received in their class and beyond. Moreover, thinking about using knowledge in real-life situations, analyzing to make different meanings, evaluating the information for a common good, and coming up with new knowledge seem impossible (Qutoshi, 2016). Thus, students need an active learning environment to generate more opportunities to develop the ability to ask questions and to interact meaningfully with other learners. The findings also showed that appropriate teaching strategies and interactive learning environments aid to facilitate the growth of higher-order thinking ability, and help students to develop flexible attitude, self-monitoring and analytical skills (Smith, Sasone \& White, 2007) that appeared to be missing in the current situation.

The research demonstrated that teaching strategies were not appropriate, and the teachers were ignoring needs of the most of the slow learners in the classroom. Findings also showed that participants were aware of their student's mental abilities and learning difficulties, yet they were not making any effort to actively involve and to motivate those students during lessons.

In conclusion, these findings showed that the majority of teachers had very basic knowledge about critical thinking and teachers need more knowledge, skills, and expertise to face these challenges successfully (Saleh \& Al-Mekkhlafi, 2017). To develop critical thinking skills in students' teachers need to engage their students in thoughtful discussion and provide them the opportunity of thinking, questioning and creativity. Trained teachers need to create interactive classrooms so that students can apply, analyze and evaluate the given information in new situations, and be able to generate new ideas to develop their deeper level of understanding of the subjects.

It was also found that teachers used to put the responsibility on the students to think critically rather than providing enough opportunities to students and to help them to think critically. Mostly, both teachers and students fall in the lowest level of the cognitive domain. They preferred rote learning and asked students to copy their answers from a book. Gabler and Schroeder (2003) argued that in the traditional classrooms, students were expected to master reading, writing, and arithmetic. In the 21 st century, students need more than these basic skills to excel in the future workplace. Whereas, the teachers found to be encouraging and appreciating only those students who were very active to answer the questions asked by the teachers, they ignored the rest of the students in their classes who are slow learners and do not ask questions. Keeping such a situation in the classroom, the teachers make students responsible and blame students' early years of schooling. Therefore, students stayed passive all the time in their classrooms. Moreover, the researchers hardly found any activity or question in the classroom which could involve students in the thinking process. 
After analysis of participant's answers, researchers came to realize that almost $100 \%$ of participants expressed their views that their classroom environment is conducive which motivates and encourages student participation. Whereas, their views were found contradictory during classroom observation and they were found to be less supportive in providing students the opportunities to think critically. It was noticed that hardly $33.3 \%$ of the teachers were aware of some of the motivational strategies, and they use different strategies to engage students in higher-order thinking processes in the classroom as compared to $66.6 \%$ of teachers, who did not engage students in developing critical thinking skills nor encourage students to participate in classroom activities.

Thus, the study revealed that there are differences between the practices and perceptions of secondary school teachers with regard to developing critical thinking skills among students. For instance, there are teachers who are aware of critical thinking and exhibit it in their practices, while the rest are teachers who are aware of critical thinking but do not exhibit it in their practices. Thirdly, teachers are aware of critical thinking, but have wrongly understood it; hence, exhibit accordingly in their practices.

\section{RECOMMENDATIONS}

Based on the key findings of the study, research recommends that schools need an education system that focuses on effective training of teachers to engage students in effective learning (Andrews, 2000; Febriatika \& Alberida, 2021). Here, effective learning means enabling students to learn and experience all six levels of learning based on Bloom's taxonomy (1956) such as remembering, understanding, applying, analyzing, evaluating, and creating new knowledge. So, schools need education for emancipation that can liberate both teachers and students to think out-of-the-box solutions to the problems to face the 21 st-century challenges either using the Oxford curriculum or adopting 'one nation one curriculum' in the future. To this end, the need is to convert schools into learning organizations (Qutoshi \& Rajbhandari, 2016), and to achieve this objective, a transforming or transformative leadership in schools is highly desirable who can develop learners as critical thinkers (Qutoshi \& Luitel, 2021).

\section{REFERENCES}

Aliakbari, M., \& Sadeghdaghighi, A. (2012). Teachers' perception of the barriers to critical thinking. Procedia-Social and Behavioral Sciences, 70, 1-5.

Al-Kindi, N. S., Al-Mekhlafi, A. M. (2017). The Practice and Challenges of Implementing Critical Thinking Skills in Omani Post-basic EFL Classrooms. English Language Teaching, 10(12), 116-133.

Andrews, S. F. (2000). Critical thinking in South Dakota public schools' grades 3, 4, and 5: The influence of teacher's behaviors; Perceptions \& attitudes [Unpublished doctoral dissertation. South Dakota, University of South Dakota].

Ball, A. L., \& Garton, B. L. (2005). Modeling higher order thinking: The alignment between objectives, classroom discourses, and assessment. Journal of Agricultural Education, 46(2), $58-69$.

Bogdan, R. C., \& Biklen, S. K. (1998). Qualitative research in education: An introduction to theory and method (3rd ed.). Needham Heights.

Choy, S. C., \& Cheah, P. K. (2009). Teacher perceptions of critical thinking among students and its influence on higher education. International Journal of teaching and learning in Higher Education, 20(2), 198-206.

Choy, S. C., \& San Oo, P. (2012). Reflective thinking and teaching practices: A precursor for incorporating critical thinking into the classroom? International journal of Instruction, 5(1), 167-182.

Connor, C. M., Morrison, F. J., \& Petrella, J. N. (2004). Effective reading comprehension instruction: Examining child x instruction interactions. Journal of Educational Psychology, 80(40), 448456

Creswell, J. W. (2014). Research Design: Qualitative, Quantitative and Mixed Methods Approaches (4th ed.). Thousand Oaks. 
Duron, R., Limbach, B., \& Waugh, W. (2006). Critical thinking framework for any discipline. International Journal of Teaching and Learning in Higher Education, 17(2), 160166.

Economic survey of Pakistan. (2011). Government of Pakistan. Retrieved from: https://www.finance.gov.pk/survey_1112.html

Elder, L., \& Paul, R. (2010). Critical thinking: Competency standards essential for the cultivation of intellectual skills part 1, Research in developmental education, 34(2), 38-39.

Etikan, I. Musa, A. S., \& Alkasssiam, R. S. (2015). Comparison of convenience sampling and purposive sampling. American Journal of Theoretical and Applied Statistics.

Febriatika, W., \& Alberida, H. (2021). Students' Critical Thinking Skills at SMAN 7 Tebo. International Journal of Progressive Sciences and Technologies, 24(2), 476-479.

Fletcher, L. S. (2011). Creative thinking in schools: Finding the "just right" challenge for students. Gifted Child Today, 34(2), 37-42.

Fredericks, J. A., Blumenfeld, P. C., \& Paris, A. H. (2004). School engagement: Potential of the concept, state of evidence. Review of Educational Research, 74(1), 59-109.

Gabler, I. C., \& Schroeder, M. (2003). Constructivist Methods for the Secondary Classroom: Engaged Minds. Boston: Pearson.

Government of Pakistan. (2006). National curriculum for general science for grade IV \& VIII. Ministry of Education Pakistan.

Gürses, A., Açıkyıldız, M., Doğar, Ç., \& Sözbilir, M. (2007). An investigation into the effectiveness of problem-based learning in a physical chemistry laboratory course. Research in science \& technological education, 25(1), 99-113.

Heard, J., Scoular, C., Duckworth, D., Ramalingam, D., \& Teo, I. (2013). Critical thinking: skills development framework. Australian Council for Educational Research. Retrieved from: http://research.acer.au/ar_misc/41

Hoodbhoy, P. (2009). Pakistan's higher education system-What went wrong and how to fix it. The Pakistan Development Review, 48(4), 581-594.

King, F., Goodson, L., \& Rohani, F. (2012). Higher order thinking skills: Definitions, strategies, assessment. Center for Advancement of Learning and Assessment. Tallahassee, FL: Florida State University.

Khoiri, A., Komariah, N., Utami, R.T., Paramarta, V., \& Sunarsi, D. (2021, February). 4Cs Analysis of 21st Century Skills-Based School Areas. In Journal of Physics: Conference Series (Vol. 1764, No. 1, p. 012142). IOP Publishing.

Kuldas, S., Hashim, S., Ismail, H.N., \& Bakar, Z.A. (2013). Reviewing the role of cognitive load, expertise level, motivation, and unconscious processing in working memory performance. Journal of Educational Psychology, 4(2), 142-169.

Lai, E.R. (2011). Critical thinking: A Literature Review. Retrieved from: http://www.pearsonassessments.com/

Lauer, T. (2005). Teaching critical-thinking skills using course content material. Journal of College Science Teaching, 34(6), 34-44.

Lewis, A., \& Smith, D. (1993). Defining higher order thinking. Theory into Practice. International journal of education, 32(3), 131-137.

Liyanage, I., Walker, T., \& Shokouhi, H. (2021). Are we thinking critically about critical thinking? Uncovering uncertainties in internationalized higher education. Thinking Skills and Creativity, 39.

Jalal, H., Buzdar, M.A., \& Naoreen, B. (2020). Effectiveness of Accreditation in Assuring the Quality of Teacher Education Programs: Exploring the Case of an Underdeveloped Country. Global Social Sciences Review, 1, 84-94.

Macagno, F., \& Bigi, S. (2020). Analyzing dialogue moves in chronic care communication: Dialogical intentions and customization of recommendations for the assessment of medical deliberation. Journal of Argumentation in Context, 9(2), 167-198.

Mahmood, S. (2017). Testing the effectiveness of a critical thinking skills intervention for initial teacher education students in Pakistan. [PhD dissertation, University of Southampton].

Maxwell, J.A. (2005). Qualitative Research Design: An Interactive Approach (2nd Ed). Thousand Oaks. 
Merriam, S.B. (1998). Qualitative Research and Case Study Applications in Education. Jossey-Bass Publishers.

National Education Policy. (2009).

Retrieved from: http://itacec.org/document/2015/7/National_Education_Policy_2009.pdf

Orland-Barak, L., \& Wang, J. (2021). Teacher mentoring in service of preservice teachers' learning to teach: Conceptual bases, characteristics, and challenges for teacher education reform. Journal of Teacher Education, 72(1), 86-99.

Orr, J.B., and Klein, M.F. (1991). Instruction in Critical Thinking as a Form of Character Education." Journal of curriculum and supervision, 6(2), 130-144.

Osterman, K.F. (2000). Students' need for belonging in the school community. Review of educational research, 70(3), 323-367.

Paul. (2010). Stapleton thinking skills and creativity. Elsevier. 5(1).

Paul, R. (2005). The state of critical thinking today. New Directions for Community Colleges, 130, $27-$ 38.

Qutoshi, S. B. (2021). Journeying Through Informing, Reforming and Transforming Teacher Education: Reflections on Curriculum Images. Journal of Transformative Praxis, 2(1), 8-18.

Qutoshi, S.B., \& Luitel, B.C. (2021). Transforming Leadership as/for Emancipation: A Journey towards Exploring Self and Beyond in the Field of Leadership, In J.A. Khaki, M.D. Shafa, G, Khan, \& S.B. Qutoshi (Eds.), Educational Leadership Policies and Practices: Voices from the Developing Countries. Oxford University Press.

Qutoshi, S.B., Tajuddin, S., Rahim, S., \& Caballero, L.B.A. (2020). Integration of computer technology in teacher education at Pakistan Public Sector University. Revista Cubana de Medicina Militar, 49(1), 37-156.

Qutoshi, S.B. (2018). Critical Reflective Practice as an Approach to Developing Transformative Living-theory. Dhaulagiri Journal of Sociology and Anthropology, 12, 107-111.

Qutoshi, S. B. (2017). Use of Technologies as Pedagogical Tools to Improve Teaching Learning Practices. TRES Journal of Educational Studies, 1(1), 41-46.

Qutoshi, S. B. (2016). Musing Through Pedagogical Approaches. In S. B. Qutoshi (2016), Creating Living Educational Theory: A Journey Towards Transformative Teacher Education in Pakistan [Doctoral Thesis].

Qutoshi, S.B., \& Rajbhandari, M.M.S. (2016). A Philosophical View on and a Technical Approach to Leading a Learning Organization. Journal of Education and Research, 6(2), 7-20.

Qutoshi, S.B., Poudel, T. (2014). Student-Centered Approaches to Teaching: What does it mean for the stakeholders of Community School, Karachi, Pakistan? Journal of Education and Research, 4(1), 19-33.

Ridho, S., Wardani, S., \& Saptono, S. (2021). Development of Local Wisdom Digital Books to Improve Critical Thinking Skills through Problem Based Learning. Journal of Innovative Science Education, 10(1), 1-7.

Scriven, M., \& Paul, R. (2008). Defining critical thinking. The Critical Thinking Community: Foundation for Critical Thinking. Retrieved from: http://www.criticalthinking.org/aboutCT/define_critical_thinking.cfm

Short, M.N., \& Keller-Bell, Y. (2021). Essential skills for the 21 st century workforce. In Research Anthology on Developing Critical Thinking Skills in Students. IGI Global.

Smith, V.G. \& Szymanski, A. (2013). Critical thinking: More than test scores. NCPEA International Journal of Educational Leadership Preparation, 8(2), 16-26.

Smith, J.L., Sansone, C., \& White, P.H. (2007). The stereotyped task engagement process: The role of interest and achievement motivation. Journal of Educational Psychology, 99(1), 99-114.

Snyder, L. G., \& Snyder, M. J. (2008). Teaching Critical Thinking and Problem-Solving Skills. The Delta Pi Epsilon Journal.

Sultana, M., \& Zaki (2015). Proposing project-based learning as an alternative to traditional ELT pedagogy at public college in Pakistan. Journal for lesson and learning studies, 5 1), 34-50.

Tempelaar, D.T. (2006). The role of metacognition in business education. Industry and Higher Education, 20(5), 291-297.

World Bank (2006). Program document for a proposed Punjab education sector development policy. Credit report no 35441-PR. 
The perceptions and practices of secondary school teachers for developing critical thinking skills

Yin, R.K. (2009). Case study research: Design and methods (4th Ed). Thousand Oaks.

Zarillo, J. (2012). Teaching elementary social studies: Principles and applications ( $4^{\text {th }}$ Ed). Pearson. 